\title{
Futures trading, spot price volatility and market efficiency: evidence from European real estate securities futures
}

Article

Accepted Version

Lee, C. L., Stevenson, S. and Lee, M.-L. (2014) Futures trading, spot price volatility and market efficiency: evidence from European real estate securities futures. Journal of Real Estate Finance and Economics, 48 (2). pp. 299-322. ISSN 1573-045X doi: https://doi.org/10.1007/s11146-012-9399-3 Available at https://centaur.reading.ac.uk/35450/

It is advisable to refer to the publisher's version if you intend to cite from the work. See Guidance on citing.

Published version at: http://link.springer.com/article/10.1007/s11146-012-9399-3

To link to this article DOI: http://dx.doi.org/10.1007/s11146-012-9399-3

Publisher: Springer

All outputs in CentAUR are protected by Intellectual Property Rights law, including copyright law. Copyright and IPR is retained by the creators or other copyright holders. Terms and conditions for use of this material are defined in the End User Agreement.

www.reading.ac.uk/centaur 
Central Archive at the University of Reading

Reading's research outputs online 


\section{Futures Trading, Spot Price Volatility and Market Efficiency: Evidence from European Real Estate Securities Future}

Article

Lee, C. L., Stevenson, S. and Lee, M. L. (2014) Futures Trading, Spot Price Volatility and Market Efficiency: Evidence from European Real Estate Securities Future. Juornal of Real Estate Finance \& Economics, 48 (2). pp. 299-322. doi: 10.1007/s11146-012-9399-3 Available at http://centaur.reading.ac.uk/40902/

It is advisable to refer to the publisher's version if you intend to cite from the work.

Published version at: http://dx.doi.org/10.1007/s11146-012-9399-3

To link to this article DOI: http://dx.doi.org/10.1007/s11146-012-9399-3

Publisher: Springer

All outputs in CentAUR are protected by Intellectual Property Rights law, including copyright law. Copyright and IPR is retained by the creators or other copyright holders. Terms and conditions for use of this material are defined in the End User Agreement. 


\section{CentAUR}

Central Archive at the University of Reading

Reading's research outputs online 


\section{Henley \\ Business School}

UNIVERSITY OF READING

\section{Futures Trading, Spot Price Volatility and Market Efficiency: Evidence from European Real Estate Securities Futures}

Accepted for publication in Journal of Real Estate Finance and Economics

Chyi Lin Lee (University of Western Sydney), Simon Stevenson (University of Reading) \& Ming Long Lee (National Dong Hwa University) 


\title{
Futures Trading, Spot Price Volatility and Market Efficiency: Evidence from European Real Estate Securities Futures
}

\author{
Chyi Lin Lee \\ School of Economics and Finance, University of Western Sydney, Locked Bag 1797, Penrith \\ NSW 2751, Australia. \\ Email: chyilin.lee@uws.edu.au
}

\begin{abstract}
Simon Stevenson
School of Real Estate and Planning, Henley Business School, University of Reading, Whiteknights, Reading, RG6 6UD United Kingdom

Email: s.a.stevenson@reading.ac.uk
\end{abstract}

Ming-Long Lee

Department of Finance, National Dong Hwa University

No. 1, Sec. 2, Da Hsueh Rd., Shoufeng, Hualien 97401, Taiwan

Email: ming.long.lee@mail.ndhu.edu.tw

Keywords: Real estate securities futures, GARCH, volatility, hedging effectiveness and Europe 


\title{
Futures Trading, Spot Price Volatility and Market Efficiency: Evidence from European Real Estate Securities Futures
}

\begin{abstract}
In 2007 futures contracts were introduced based upon the listed real estate market in Europe. Following their launch they have received increasing attention from property investors, however, few studies have considered the impact their introduction has had. This study considers two key elements. Firstly, a traditional GARCH model, the approach of Bessembinder \& Seguin (1992) and the Gray's (1996) Markov-switching-GARCH model are used to examine the impact of futures trading on the European real estate securities market. The results show that futures trading did not destabilize the underlying listed market. Importantly, the results also reveal that the introduction of a futures market has improved the speed and quality of information flowing to the spot market. Secondly, we assess the hedging effectiveness of the contracts using two alternative strategies (naïve and OLS models). The empirical results also show that the contracts are effective hedging instruments, leading to a reduction in risk of $64 \%$.
\end{abstract}




\section{Futures Trading, Spot Price Volatility and Market Efficiency: Evidence from European Real Estate Securities Futures}

\section{1: Introduction}

The introduction of dedicated index derivative contracts has only been a relatively recent phenomenon in the listed real estate market. This is despite their long history and trading in the broader equity markets, other financial assets and in some markets the provision of stock option contracts for real estate firms. Furthermore, the importance of index futures contracts based on real estate securities has long been highlighted (e.g. Oppenheimer, 1996; Liang et al., 1998; Newell \& Tan, 2004; Clayton, 2007; Ong \& Ng, 2009). In principle, an index futures contact would offer an opportunity for institutional investors to reduce the risk of their portfolios, provide an alternative means of gaining exposure to the real estate security sector and to enhance the liquidity of listed real estate investment. Despite these factors it was only in 2002 when the first index futures contract specifically concerned with the real estate equity sector was launched. This first contract was introduced by the Australian Securities Exchange and based on the S\&P/ASX 200 A-REIT Index. This was followed by contracts being developed by the Chicago Board of Trade in 2007 (Dow Jones US Real Estate Index Futures) and the Tokyo Stock Exchange in 2008 when J-REIT futures were launched. In October 2007, the NYSE LIFFE Euronext introduced two futures contracts specifically concerned with the European market. Importantly, the listed real estate sector in Europe has expanded considerably over the course of the last decade, as of June 2011, there were a total 830 real estate stocks with a total market capitalization of $€ 321.1 \mathrm{bn}$. This equates to $24 \%$ of the global listed property market (EPRA, 2011). 
Europe does provide an interesting case study in the examination of the introduction of index futures for real estate security markets. Unlike the contracts launched in Australia, U.S. and Japan, they are not country specific. Rather, they are based on the FTSE ERPA/NAREIT Europe and FTSE EPRA/NAREIT Eurozone indices. This raises a number of issues, in particular, whether the pan-European nature leads to differences in terms of the impact upon the underlying market and also the hedging effectiveness of them. After the initial establishment period in 2007-2008, the market has received increasing attention from investors. Over 2007-2010, the trading volume of the Europe (Eurozone) index futures contracts had increased significantly from €81.7million (€63.8million) to €692million (€130million (NYSE, 2011). This reflects the significance of futures as an important tool for institutional investors in their portfolio management.

Although the European real estate securities futures market has received increasing attention from institutional investors, virtually no empirical work has been undertaken. This study aims to fill in this gap in the literature by examining a number of key elements concerning the introduction of index futures in the European listed real estate market. Specifically, it investigates whether the introduction of the futures market had a destabilizing impact upon the underlying listed real estate sector. The impact of introducing a futures market on the volatility and market efficiency of the underlying spot market has been of great interest to policy makers, practitioners and academics. This study therefore, aims to provide empirical evidence concerning the linkage between futures-trading and the volatility of the spot market. In addition, the study also investigates the hedging effectiveness of the futures contracts. This issue is obviously of enhanced importance in light of the negative impact of the recent financial crisis on global real estate securities. Thus, an investigation of the hedging 
effectiveness will enable more informed investment decision-making regarding the role of such contracts from a fund management perspective. This is particularly important in the case of Europe due to the use of continental, rather than national, indices.

This study contributes to the literature in a number of ways. Firstly, this study is the first real estate study to consider the impact on the underlying sector resulting from the introduction of index derivatives. Specifically, it investigates whether the onset of a real estate futures market would destabilize or stabilize the underlying property market. Although extensive finance studies have examined the impact of futures trading on the volatility of the underlying spot market, these studies focus on futures contracts written on general stocks, foreign currencies, interest rates and commodities. No study has been dedicated to real estate futures. Clearly this is expected given the relatively short time for which real estate futures have been traded. Importantly, futures contracts written on real estate securities are smaller and less heavily traded compared with stock futures. For instance, the trading volume of the FTSE EPRA/NAREIT Europe index futures in 2010 was only 78,147 contracts, whereas the trading volumes of the FTSE 100 and CAC40 index futures were 37.6 million contracts and 44.6 million contracts respectively (NYSE, 2011). In addition, securitized real estate, particularly REITs exhibit some unique features compared to general stocks (i.e. high dividend payout). By considering these unique characteristics of securitized real estate and futures contracts written on real estate securities, a specific investigation of securitized real estate futures is essential to enable more informed and practical investment decision-making regarding the role of securitized real estate futures. Moreover, general stock futures offer mixed results on the impact of futures trading. To fully understand the impact of futures trading on the volatility of the underlying market, it is necessary to examine whether there is a sector effect 
in futures trading. Given securitized real estate can be viewed as a relatively large and homogenous industry group, securitized real estate futures provide a good industry for evaluating the impact of futures trading on the volatility and market efficiency of the spot market at the sector level. The findings are important and are expected to offer insights to real estate investors and financial regulatory authorities in relation to whether or not the establishment of futures market would facilitate the development of listed property markets.

Secondly, this study, to the best of our knowledge, is the first formal attempt to examine the volatility dynamics of securitized real estate in the volatility regime framework. Extensive studies have examined the volatility dynamics of securitized real estate (Stevenson, 2002; Cotter \& Stevenson, 2006, 2008; Liow, 2009; Liow \& Ibrahim, 2010). But this study is different from the abovementioned studies in the sense that we applied the Gray's (1996) Markov-switching-GARCH model in the securitized real estate market for the first time. Although the model has been recently applied to various stock markets, no study has analyzed the nature of the volatility regimes of real estate. Importantly, the Markovswitching-GARCH model allows for endogenous volatility regime shifts or structural breaks (Bohl et al., 2011, Nomikos \& Pouliasis, 2011). Recognizing the feature of volatility regime shifts is increasing importance in light of many real estate markets have experienced significant volatility shifts due to the global financial crisis; thereby the model would able to provide more insightful empirical and graphic evidence of how the introduction of a real estate futures market changes the volatility structure of the underlying spot market.

Thirdly, the relationship between volatility and the level of futures trading, including trading volume and open interest, are also investigated for the first time in the real estate context. The 
results are expected to offer insights to institutional investors whether futures-trading contains important information regarding the spot market. This would also offer some evidence of how futures-trading affect the market efficiency of real estate. Fourthly, unlike Lee \& Lee (2012), this paper based on the FTSE EPRA/NAREIT Europe and Eurozone indices provides empirical evidence on the hedging effectiveness of real estate futures that are not country specific. This unique feature allows us to examine the contracts use in a hedging context relates to the cross-border nature of the indices used. Importantly, futures contracts based on continental indices are not popular in the futures market and were underresearched. Thus the findings will also offer new insights to policy makers in relation to the choice of launching futures contracts on an international basis or country specific. Furthermore, the paper is the first attempt to assess the extent of risk reduction using European futures to hedge the return of European real estate securities. The results and their implications will help to assess the economic usefulness of the derivatives market.

The remainder of this paper is organized as follows. The following section provides a brief literature review on real estate security futures. The impact of index futures trading on the volatility of the underlying market is also reviewed. Section 3 details the data used and the methodological framework adopted. Section 4 reports and discusses the empirical findings, whilst the final section provides concluding comments.

\section{2: Literature Review}

The impact of futures trading on the volatility of the underlying spot market has been intensely debated in the finance literature. This literature extends back to early papers that pre-date the widespread introduction of financial futures in the early seventies. These early 
studies primarily centered their arguments on two key positions. On one hand, there was a belief among market participants and policy makers that speculators in a futures market would lead to a destabilization of spot prices. Kaldor (1939) posited that speculators could destabilize prices by ignoring market fundamentals and speculating mainly based on other players' behavior. He therefore argued in favor of extensive regulation for futures markets. In contrast, other early studies argued that futures markets would have a stabilizing effect on the underlying spot market. This stance was based upon the argument that futures markets would attract additional traders to the cash/spot market and therefore improve the price discovery process, leading to enhanced liquidity and reduced volatility (Working, 1953; Cox, 1976).

Numerous empirical studies have assessed the impact of index futures trading in various markets. Some seminal empirical studies, such as Figlewski (1981), reported that futures trading in GNMA futures securities led to an increase in monthly price volatility. Stein (1987) also reported higher spot market volatility in post-futures periods. However, Santoni, (1987) found little change in the S\&P 500 index following the introduction of futures contracts. Comparable evidence is also reported by Edwards (1988a, 1988b). Whilst Aggarwal (1988) noted that the post-futures period displays greater volatility, the author also found that volatility in all markets, whether futures contracts were present or not, had increased. Hence the increase in volatility could not necessarily be attributed to the introduction of derivatives and the resulting futures trading. Harris (1989) also supported this hypothesis in that the increase in volatility could be linked to other index-phenomenon. Interestingly, Stoll and Whaley (1988) found that the introduction of futures contracts reduced the volatility of the underlying spot market. More recently, Pericli and Koutmos (1997) argued that calls for a tightening in the regulation of index futures are unwarranted as 
no further structural changes, apart from the impact of the October 1987 crash, are found in terms of the volatility of the S\&P 500 .

In the U.K., Antoniou \& Holmes (1995) found an increase in the volatility of the FTSE 100 index in the post-futures period they considered. Importantly, they also illustrated that the increase in volatility is a direct result of an increase in the flow of information into the market. They therefore argue that the increased volatility should not necessarily, or immediately, be interpreted in a negative sense. This argument is also supported by Lee \& Ohk (1992). They demonstrate that significant increased volatility is evident soon after index futures were launched in Japan, the U.K. and the U.S. Their empirical findings also showed that the creation of a futures contract makes the stock market relatively more efficient, as volatility shocks are more quickly assimilated into the underlying market. Moreover, Darrat \& Rahman (1995) demonstrate that futures trading is not a significant factor in stock market volatility.

Interestingly, Chang et al. (1999) showed that whilst the onset of Nikkei 225 futures trading on the Osaka Securities Exchange slightly increased the volatility of the spot market, this was not the case with their introduction on the Singapore International Monetary Exchange. Gulen \& Mayhew (2000) examined stock market volatility before and after the introduction of stock index futures trading in 25 developed and emerging countries. Interestingly, they only found a noticeable increase in conditional volatility in the U.S. and Japan. In the remaining 23 markets there was either a negligible effect or the conditional volatility actually fell. Bae et al. (2004) found that futures trading in Korea increased spot price volatility but also market efficiency. The results do however point to a reduction in the effect over time. 
Indeed, the impact appeared to vanish following the addition of options trading. More recently, Bohl et al. (2011) utilized a Markov-switching GARCH model in the context of the Polish market and showed that the introduction of index futures does not seem to influence the volatility of the underlying equity market. In addition, several studies have investigated the volatility-volume relation in futures markets (e.g. Bessembinder \& Seguin, 1992, 1993; Daigler \& Wiley, 1999; Watanabe, 2001). In general, linkages between volatility and not only volume but also open interest are reported.

In contrast to the large number of studies to have considered index futures generally, the specific literature concerning real estate has been limited. In large part this has been due to their recent introduction and to the small number of markets in which such contracts are traded. The majority of the real estate literature has either considered the introduction of derivatives on the direct market (e.g. Lecomte \& McIntosh, 2006; Wong et al., 2006; Hoesli \& Lekander, 2008; Lizieri et al., 2011) or considered how to produced so-called hedged REIT indices (e.g. Giliberto, 1993; Stevenson, 2000). Studies such as Oppenheimer (1996) and Liang et al. (1998) demonstrated the importance of introducing specific real estate related contracts as futures contracts written on stocks, interest rates, commodities and metals offer very weak hedging performance in a real estate stock context. Comparable evidence is also reported by Chaudhry et al. (2010), although this study did find that contracts based on energy-related products can provide some hedging benefits.

Newell \& Tan (2004) is one of the first empirical studies to consider specific real estate security futures contracts. Utilizing data following the introduction of index futures in Australia in 2002, they showed that Australian institutional investors can use such futures 
contracts to protect in the context of hedging their REIT (Listed Property Trust) portfolios. More recently, Lee \& Lee (2012) find that A-REIT and J-REIT futures are effective hedging instruments in which a risk reduction level of 59\% and $45 \%$ is reported for Australian and Japanese REITs respectively. Their results also reveal that REIT futures offer superior hedging results compared to futures contracts based on stocks, interest rates and foreign exchange rates. Finally, Lee (2009) documents a strong volatility spillover effect between AREITs and A-REIT futures, arguing that futures trading enhances the price discovery process of A-REITs. Newell (2010) notes that the role of futures contracts in Australia increased during the recent financial crisis. As can be seen, there have been relatively few studies on real estate stock specific futures, and no papers have as of yet considered the European case. Moreover, there is no real estate study to examine the effect of futures trading on the volatility and market efficiency of the underlying spot market.

\section{3: Data and Methodological Framework}

\section{1: Data}

To assess the impact of futures trading on volatility, daily closing prices from the spot market were collected for the period October 2004 to September 2010. Following Antoniou et al. (1998), the analysis was conducted with the use of data for the period three years prior to through three years after the introduction of futures trading ${ }^{1}$. The two indices on which the contracts are based, namely the FTSE ERPA/NAREIT Europe and Eurozone indices, are used to represent the performance of the underlying market. The time period available for the futures markets spans from October 2007 to September 2010. All data was obtained from Thompson Reuters Datastream. The returns of both the underlying indices and the futures contracts were defined as the first difference in the natural logarithm of the indices. In 
addition, the volume and open interest of both futures contracts were extracted from Thompson Reuters Datastream. Table 1 presents the specifications of the two futures contracts. The contracts are traded on the NYSE LIFFE Euronext in Paris. Both contracts have a similar trading cycle, with expiry dates in March, June, September and December. As can be observed, the contract multiplier of both is only $€ 10$ per index point, and therefore both can be considered as mini-futures. These principal features and specifications are similar to those in place in Australia and Japan (Lee \& Lee, 2012). It should be noted that the data were collected in the Euro $(€)$ in respect to both futures contracts are traded in the Euro ${ }^{2}$.

\section{\{Insert Table 1\}}

The summary statistics reveal that the return and risk levels of real estate securities in Europe and in the Eurozone are very comparable. This is not unsurprising as the primary difference in the composition of the two indices is the exclusion markets such as the U.K. in the Eurozone index. The normality tests reveal that the return distributions of the two indices are not normally distributed. These findings also imply the presence of ARCH effects, which is confirmed by the LM tests, reflecting the presence of volatility clustering effects. Given that daily data is used in this study, the presence of volatility clustering is to be expected. This is not only a common finding in capital market assets generally, but in listed real estate markets specifically (Cotter \& Stevenson, 2006, 2008; Jirasakuldech et al., 2009) ${ }^{3}$.

\section{2: The Impact of Futures Trading on Spot Volatility}

The empirical analysis consists of two key components. The first examines the impact of futures trading on the volatility and market efficiency of the underlying spot market. The 
second is concerned with the hedging effectiveness of the futures contracts. To assess the impact of futures trading, three alternative models were utilized, namely a $\operatorname{GARCH}(1,1)$ specification, secondly the model proposed by Bessembinder \& Seguin (1992) and thirdly a Markov-switching-GARCH model. The $\operatorname{GARCH}(1,1)$ model was estimated in order to examine whether the introduction of a futures market has a significant impact on the spot market. It is specified as follows:

$$
\begin{aligned}
& \mathrm{R}_{\mathrm{t}}=\mathrm{a}_{0}+\mathrm{a}_{1} \mathrm{R}_{\mathrm{t}-1}+\mathrm{a}_{2} \mathrm{GFC}+\mu_{\mathrm{t}} \\
& \mathrm{h}_{\mathrm{t}}=\alpha_{0}+\alpha_{1} \varepsilon_{\mathrm{t}-1}^{2}+\alpha_{2} \mathrm{~h}_{\mathrm{t}-1}+\alpha_{3} \mathrm{D}_{\mathrm{F}}
\end{aligned}
$$

where $R_{t}$ represents the returns on the respective index, GFC is a dummy variable taking on the value 1 for the period around the recent financial crisis (September 2007-June 2009) ${ }^{4}$, and zero otherwise. $\mathrm{D}_{\mathrm{F}}$ is a dummy that takes the value zero in the pre-futures period and unity following October 2007 and the introduction of the contracts. The coefficient for the GFC dummy is expected to be negative, given that the crisis had a strong negative impact on the listed real estate sector. There is however, no a priori sign for $\mathrm{D}_{\mathrm{F}}$. This is due to the alternative theoretical viewpoints concerning the possible impact of futures trading on the volatility of spot prices. The analysis was also carried out using two sub-periods. This was undertaken in order to examine the relationship between information and volatility following the onset of futures trading. Specifically, the results contribute to the debate on whether futures trading activities would enhance the market efficiency. We follow the methodology of Antoniou \& Holmes (1995), with entire sample period partitioned into two, denoting the pre and post futures periods. The sample is therefore split as of October $1^{\text {st }} 2007$. The behaviors of the parameters in the GARCH equations for the two sub-periods are then subsequently compared. A comparison of these coefficients will offer some insights in relation to whether 
the market efficiency has been enhanced. According to Antoniou \& Holmes (1995), the coefficient of $\mathrm{ARCH}\left(\alpha_{1}\right)$ relates to the lagged squared error term. Thus, it can be viewed as a gauge for "recent news". However, the coefficient of GARCH $\left(\alpha_{2}\right)$ relates to the lagged variance term; thereby it represents "old news". If the efficiency of the European real estate market has been improved due to futures trading, the role of "recent news" should be enhanced. Therefore, it is hypothesized that a higher ARCH coefficient and a lower GARCH coefficient are observed in the post-futures trading.

The approach of Bessembinder \& Seguin (1992) was also generalized in order to investigate the relationship between the volatility of the underlying index and the level of futures trading activity. Importantly, the analysis will offer some evidence of how futures trading changes the market efficiency of the underlying spot market. An Autoregressive Integrated Moving Average (ARIMA) model was employed to decompose the time series' of both trading volume and open interest in the futures contracts into expected and unexpected components. According to Bessembinder \& Seguin (1992) the unexpected component can be interpreted as the daily shock, whereas the expected component should reflect the forecastable level of futures trading. This model has been widely used in the finance literature in papers such as Daigler and Wiley (1999); Gulen and Mayhew (2000) and Watanabe (2001). ${ }^{5}$ We then consider how these components affect the volatility of the spot market by including them as additional explanatory variables in the variance equation of the GARCH model. This approach is consistent with Gulen \& Mayhew (2000). The augmented variance equation can be represented as follows:

$$
\begin{aligned}
& \mathrm{h}_{\mathrm{t}}=\alpha_{0}+\alpha_{1} \varepsilon_{\mathrm{t}-1}^{2}+\alpha_{2} \mathrm{~h}_{\mathrm{t}-1}+\alpha_{3} \text { ExpVol }+\alpha_{4} \mathrm{Un} \exp \text { Vol }+\alpha_{5} \text { ExpOI }+\alpha_{6} \mathrm{Unexp} \text { OI }+ \\
& \alpha_{7} \text { Mon }+\alpha_{8} \text { Tue }+\alpha_{9} \text { Wed }+\alpha_{10} \text { Thu }
\end{aligned}
$$


where ExpVol and Unexp Vol represents the expected and unexpected components of volume, ExpOI and Unexp OI are the expected and unexpected components of open interest and Mon, Tue, Wed and Thu are daily dummies. It is hypothesized that the expected components of volume and open interest have a negative impact on volatility, whereas market volatility is positively related to the unexpected components of volatility and open interest. As discussed by Bessembinder \& Segiun (1992), a negative link between expected volume and volatility would suggest that higher futures-trading enhances the rate of information flow. In addition, an inverse link between expected open interest and volatility is also hypothesized in which it indicates that futures markets improve liquidity and market depth; thereby the volatility of spot prices can be reduced. Furthermore, insignificant coefficients on daily dummies would be expected if the market efficiency of European real estate stocks has been enhanced following the onset of futures trading.

To capture the role of regimes, a Markov-Switching-GARCH model was also performed. The model was developed by Gray (1996) where the conditional regime variance processes are a function of the conditional expectation of the overall variance. Specifically, it combines Markov-switching with GARCH effects. The model consists of four elements: the conditional mean, the conditional variance, the regime process and the conditional distribution. The Gray's (1996) Markov-switching-GARCH model can be estimated as follows:

Mean Equation:

$\mathrm{R}_{\mathrm{t}}=\mathrm{a}_{0 \mathrm{i}}+\mathrm{a}_{1 \mathrm{i}} \mathrm{R}_{\mathrm{t}-1}+\mu_{\mathrm{t}} \quad$ for $\mathrm{i}=1,2$

Variance Equations: 


$$
\begin{aligned}
& \mathrm{h}_{\mathrm{it}}=\alpha_{0 \mathrm{i}}+\alpha_{1 \mathrm{i}} \varepsilon_{\mathrm{t}-1}^{2}+\alpha_{2 \mathrm{i}} \mathrm{h}_{\mathrm{t}-1} \\
& \mathrm{P}(1,1)=\operatorname{Pr}\left[\mathrm{S}_{\mathrm{t}}=1 \mid \mathrm{S}_{\mathrm{t}-1}=1\right] \text { and } \mathrm{P}(1,2)=\operatorname{Pr}\left[\mathrm{S}_{\mathrm{t}}=1 \mid \mathrm{S}_{\mathrm{t}-1}=2\right]
\end{aligned}
$$

where in all formulae the subscript (i ) denotes the regime in which the process is at time t. It is hypothesized that a higher degree of persistence in the variance, measured by the sum of $\alpha_{1 \mathrm{i}}+\alpha_{2 \mathrm{i}}$ coefficients $\left(\rho_{\mathrm{i}}\right)$, is observed in the high-volatility regime. It is also expected that volatility shocks do not have a permanent effect in which a regime-specific volatility shocks will die out in finite time $\left(\rho_{\mathrm{i}}<1\right)$.

\section{3: Hedging Effectiveness}

The second part of the empirical analysis examines the economic significance of European listed real estate futures by assessing their hedging effectiveness using two alternative hedging strategies. The first is a naïve hedging strategy, assuming a hedge ratio of 1 . In the second Ordinary Least Square (OLS) is used to estimate the optimal hedge ratio. Following Figlewski (1984), the OLS hedge can be estimated as follows:

$$
\mathrm{RES}_{\mathrm{i}, \mathrm{t}}=\alpha_{\mathrm{i}}+\beta_{\mathrm{i}} \mathrm{F}_{\mathrm{t}}+\varepsilon_{\mathrm{i}, \mathrm{t}}
$$

where $\operatorname{RES}_{\mathrm{i}}(=1,2)$ represents the FTSE ERPA/NAREIT Europe and Eurozone indices; F is the futures returns and $\alpha_{\mathrm{i}}$ and $\beta_{\mathrm{i}}$ are the constant and coefficient to be estimated. The coefficient $\beta_{\mathrm{i}}$ represents the hedge ratio to be used. Following Andani et al. (2009), we decompose the data into two periods. The in-sample period was utilized to estimate the optimal hedge ratio and extended from October 2007 to July 2008. The second period, July 
2008 to September 2010, was used for the out-of-sample testing. As highlighted by Holmes (1996), the use of a longer trading window is preferred in order to avoid changing the hedge too often and reduce the unbeatable transaction costs. A 20-day window was employed, in which the OLS model was re-estimated every 20 days. Therefore, the OLS hedge ratios are time-varying. The estimated hedge ratios were also used to form a hedged portfolio in the out-of-sample period in a 20-day trading window. The hedging effectiveness of a hedge was measured by the reduction in volatility obtained by applying the two alternative hedging strategies. This can be represented as follows:

$$
\text { Risk reduction }=\frac{\sigma_{\mathrm{u}}-\sigma_{\mathrm{h}}}{\sigma_{\mathrm{u}}} \times 100
$$

where $\sigma_{\mathrm{u}}$ is the standard deviation of returns on the unhedged position; $\sigma_{\mathrm{h}}$ is the standard deviation of returns on the hedged position.

\section{4: Empirical Results and Discussion}

\section{1: Impact of Futures Trading on Volatility}

Table 2 reports the impact of futures trading on the volatility of the spot market through the estimation of the GARCH(1,1) model detailed previously. Panel A reports the results relating to the mean equation of the model, whilst the coefficients from the variance equation are detailed in Panel B. Panel A shows that the financial crisis had an inverse impact upon the FTSE EPRA/NAREIT Europe and Eurozone Indices. Specifically, the coefficients of the dummy variable are negative and statistically significant, indicating that the crisis had a significant negative impact upon the listed real estate market in Europe. The results from the variance equation, shown in Panel B, reveal that futures trading did not significantly increase the volatility of the wider overall Europe index. The positive, but statistically insignificant, 
coefficient for the dummy variable representing the introduction of the futures contracts $\left(\alpha_{3}\right)$ suggests that whilst volatility did increase following October 2007, it did not do so to a statistically significant extent. This would support the hypothesis that the introduction of futures trading did not have a discernible impact on underlying spot price volatility. These results are consistent previous mainstream finance work such as Edwards (1988a, 1988b) and Darrat \& Rahman (1995). This finding can be interpreted as supporting the notion that introduction of the contracts did not destabilize the spot market. In contrast, when the Eurozone index is considered the results show that in the post-futures period underlying volatility is not only higher but is so to a statistically significant extent. However, it does need to be emphasized that the onset of futures trading may not be either the sole nor primary cause of this increase in volatility. Indeed, given the timing of the inception of futures trading, in late 2007 , it is perfectly natural to attribute at least some of the increase to the events surrounding the financial crisis. Although a dummy variable representing the financial crisis is included in the mean equation, the second dummy may be also capturing information from the financial crisis.

\section{\{Insert Table 2\}}

Therefore, to further differentiate the impact of the two events, the onset of futures trading and the financial crisis, a time dummy was used to gauge the influences of these two events separately. Specifically, we use two time dummies to disaggregate the sample into three periods. These are the pre-futures period, the primary financial crisis period and a final period following this. The first dummy $\left(\mathrm{D}_{\mathrm{F}}\right)$ used takes the value of unity during the period of October 2007 to December 2008 and zero otherwise, thereby capturing the impact of events 
during the height of the crisis. The second dummy ( D2 $2_{F}$ ) takes on a value of unity in the period after January $2009^{6}$.

In the case of the overall Europe Index, the estimated coefficients of $\mathrm{D} 1_{\mathrm{F}}$ and $\mathrm{D} 2_{\mathrm{F}}$ are positive, indicating that higher volatility is evident in Periods 2 and 3 compared with the level observed in the pre-futures/pre-crisis period. However, as with original findings, estimated coefficients are not significant at conventional levels. This would therefore suggest that the introduction of futures did not result in a significant increase in the volatility of the European property securities market. The results for the Eurozone index and contracts do however maintain their differences. The dummy variable for Period $2\left(\alpha_{3}\right)$ is not only positive but also statistically significant. This would suggest that listed real estate exhibit significantly higher volatility in the October 2007-December 2008 period in comparison with the pre-October 2007 period. However, the results for the final period are not significant, implying that volatility in 2009 and 2010 are not higher than pre-October 2007. These results do make strong intuitive sense in a number of respects. Firstly, they imply that the initial increase in volatility was not due to the introduction of derivatives trading, but rather can be attributed to the financial crisis and the large scale uncertainty that characterized capital markets during late 2007 and 2008. This reinforces the earlier argument that the increase in spot price volatility in the Eurozone was not necessarily caused by the start of futures trading. This view is given additional weight in that the results for the post 2008 period are insignificant. Therefore, even if futures trading had contributed to an immediate increase in volatility term, this impact was short lived and dissipated very quickly. Overall the results are consistent with 
many previous empirical studies in the stock market that have reported no significant increase in volatility that attributed to introduction of futures trading ${ }^{7}$.

\section{2: Sub-Period Analysis and the Transmission of Information}

Given that our empirical findings indicate that the introduction of futures trading did not increase spot price volatility, the next concern is whether there is any associated gain with the onset of futures trading. To address this issue, the sub-period analysis detailed in Section 3 is undertaken, with the results reported in Tables 3 and 4 . A comparison of the results before and after the establishment of futures trading shows interesting findings in the case of the FTSE ERPA/NAREIT Europe index. It can be seen from Table 3 that the value of $\alpha_{0}$ has increased slightly in the post-futures period, signifying a minor increase in the unconditional variance. This further supports the results from Table 2, in which the volatility of the overall European real estate securities market is higher in the post-futures period than prior to the contracts being launched. Moreover, an increase in $\alpha_{1}$ post-futures also suggests an increase in volatility. Importantly, the increase implies that the introduction of the contracts has facilitated the information transmission process, in that "recent news" is incorporated into spot prices more rapidly. It should be noted that the coefficient of $\alpha_{1}$ relates to the lagged squared error term. Thus it links the impact of "recent news", in terms of the arrival of information yesterday, on price changes. Given that futures trading would offer more information to market participants, it would be reasonable to expect that the impact of "recent news" would increase with the onset of real estate security index futures. Importantly, the increase of the coefficient $\alpha_{1}$ further confirms this hypothesis in that the efficiency of the European listed property market has improved. 


\section{\{Insert Tables 3 and 4 \}}

The enhancement of market efficiency is further supported by the reduction of the coefficient of $\alpha_{2}$. The coefficient of $\alpha_{2}$ can be viewed as acting a gauge for "old news" in the sense that it relates to the lagged variance term. A fall in the value of $\alpha_{2}$ is found by comparing $\alpha_{2}$ before (0.917) and after (0.868) futures trading, demonstrating that "old news" would have less impact on today's price changes. This can be explained by the enhancement of market efficiency in which the arrival process of new information in the cash market has been improved. More specifically, the increased rate of information flow, shown through an increase in $\alpha_{1}$, is expected to decrease the uncertainty about previous news $\left(\alpha_{2}\right)$. Therefore, in the presence of futures trading, "old news" has less impact in determining the volatility of the real estate securities market.

Comparable results are also documented in Table 4 for the FTSE EPRA/NAREIT Eurozone index. It can be noted that the values of $\alpha_{0}$ and $\alpha_{1}$ have both risen from the pre-futures figures, whereas $\alpha_{2}$ has fallen slightly from 0.874 to 0.837 . The results imply that, although the introduction of futures does seem to increase spot market volatility in the Eurozone, the increase in $\alpha_{1}$ coupled with a drop in $\alpha_{2}$ suggest that "recent news" is being incorporated into prices more quickly. The enhanced of information flow in recent news has also diminished the role of "old news" that is captured by $\alpha_{2}$. This implies that futures trading has increased the efficiency of the listed real estate market in the Eurozone. In other words, establishing a real estate futures market has had a stabilizing effect on the spot market. All of 
these findings would imply that the introduction of real estate specific futures contracts have increased the flow of information and enhanced the spot market efficiency. The findings are similar to those reported in previous studies on the broader equity markets (Antoniou \& Holmes, 1995; Lee \& Ohk, 1995; Bohl et al., 2011). In effect, introducing of futures trading has led to increased efficiency in terms of the transmission of information to the underlying real estate equity market. Furthermore, this finding offers some support for the presence of a stabilizing effect in which futures trading provides more information on expected prices.

\section{3: Volatility and Futures Trading Activity}

The previous section provided some indication that the introduction futures trading in European listed real estate markets has improved the flow of information in real estate equities. To extend this analysis we test whether there appears to be a relationship between the volatility of the underlying index and the level of futures-trading activity, as proxied by both trading volume itself and also open interest. The results from this analysis are presented in Table 5 and reveal a significant negative coefficient with respect to expected futures volume for both Europe and Eurozone indices. This would imply that higher expected futures trading volume provides more price expectation information, thus leading to a reduction in the volatility of spot prices. This is a similar finding to that reported by Bessembinder \& Seguin (1992) who argue that higher futures trading enhances the rate of information flow and therefore reduces the volatility of the underlying market ${ }^{8}$. It should however be noted that the expected volume coefficient for the Eurozone index is not significant at conventional levels. This could be explained through the low trading volume evident in the futures contracts for the Eurozone index. This reduced volume not only implies reduced market depth in comparison to the Europe wide index and contract, but it may also have implications 
in terms of information flows. Turning our attention to the unexpected component of volume, the coefficients are positive, even both are statistically insignificant. The documented positive relation between unexpected volume and volatility is intuitively appealing in that information shocks are expected to move prices and generate trading in both markets. Therefore, it would be expected to see a positive link between unexpected volume and spot volatility, as found in papers such as Bessembinder \& Seguin (1992) and Watanabe (2001) in the U.S. and Japanese stock index futures markets respectively.

\section{$\{$ Insert Table 5 $\}$}

With respect to expected open interest, we find, like Bessembinder \& Seguin (1992) and Gulen \& Mayhew (2000), that it has a negative impact on volatility, suggesting that futures markets improve market depth and thus have an underlying stabilizing influence. This finding also offers some indirect support to Bessembinder \& Seguin (1992) in which the expected open interest component is an appropriate proxy for market depth in that it can be viewed as a measure of the number of traders or the amount of capital dedicated to a market at the beginning of a trading session. Again the insignificance of the coefficients in the Eurozone case may be attributed to its low trading activity. In addition, an insignificant coefficient with respect to unexpected open interest is evident in both markets. This means that the unexpected component of open interest has little impact on spot price volatility. The minor role of this variable is also documented by Bessembinder \& Seguin (1992). In brief, our results would indicate that the volatility of real estate securities is mitigated when the background level of futures activity is high. This further reinforces the role of futures trading 
in market volatility. Indeed, the findings support the view that the introduction of the futures markets can improve liquidity and depth in the underlying market.

Another result worth noting is that the coefficients for the daily dummies are statistically insignificant, reflecting that there is no significant calendar anomaly in the European listed property market. The results are contrary to findings from stocks (Bessembinder \& Seguin, 1992) and previous results from the European real estate securities markets (Lenkkeri et al., 2006; Brounen \& Ben-Hamo, 2009). This may be related to the improved efficiency over time. Whilst this is a possible cause, particularly given the evidence provided earlier in this paper with respect to improved flow of information, the results may just be specific to our sample.

4.5 The Role of Regimes and the Onset of Futures Trading Recently, Bohl et al. (2011) suggested the importance of capturing regime shifts or structural breaks in the volatility process in examining the effect of futures trading. This is particularly important for the European real estate market in light of a structural break has been evident in previous sections. Therefore, the Gray's (1996) Markov-Switching-GARCH model has been employed. The estimated results are presented in Table 6 .

\section{$\{$ Insert Table 6\}}

Panel A of Table 6 shows that all coefficients $a_{11}$ and $a_{12}$ are positive and statistically significant, suggesting a positive first-order autoregressive structure in the European real estate securities market. The estimates in Panel B confirm the existence of two states. The 
first state is characterized by a high-volatility regime and the second regime is labeled as a low-volatility state. A higher persistence to shocks, indicated by $\rho_{\mathrm{i}}=\alpha_{1 \mathrm{i}}+\alpha_{2 \mathrm{i}}$, is also evident in the high-volatility regime. Specifically, the persistence coefficients in the high volatility regime for the FTSE EPRA/NAREIT Europe and Eurozone indices are 0.899 and 0.951 respectively. On the other hand, the estimates in the low volatility regime $\left(2^{\text {nd }}\right.$ regime) are in relatively smaller magnitudes in which the coefficients range from 0.203 to 0.473 . These results also reflect that the conditional volatility is stationary in all regimes and imply that volatility shocks die out in finite time. The findings are in line with other studies in the finance and futures literature such as Gray (1996), Bohl et al. (2011) and Nomikos and Pouliasis (2011). Panel C reports the unconditional probabilities of each model. The coefficients of $\mathrm{P}(1,1)$ are close to one and $\mathrm{P}(1,2)$ are close to zero, indicating that both regimes are very persistence. Finally, the Ljung-box statistics in Panel D indicate the models are correctly specified. Overall, the results reveal that the dynamics of the variance process of European securitized real estate are different under the two regimes (high- and low-volatility regimes). Therefore, it is essential to capture the volatility dynamics of real estate in both regimes.

\section{\{Insert Figures 1 and 2\}}

Figures 1 and 2 present some graphic evidence in relation to the impact of futures trading on the listed real estate markets in Europe and the Eurozone. As discussed Bohl et al. (2011), if the futures trading did destabilize the spot market, a clear cut permanent increase in spot market volatility should be evident after the introduction of futures trading. For the FTSE EPRA/NAREIT Europe index, a period of high conditional variance began in August 2007 
and ended in April 2008. After about 3 months of low-volatility, a phase of high volatility till August 2009 was recorded again. Thereafter, the market remained in the low-volatility phase until the end of the sample period despite some spikes in October 2009 and April 2010. The patterns have clearly suggested that the conditional variance of the FTSE EPRA/NAREIT Europe index did increase before the introduction of futures trading. In addition, the temporarily lower volatility from May 2008 to July 2008 and the low-volatility phase after September 2009 have refuted the destabilization hypothesis that suggests a permanent increase in spot market conditional variance after the onset of futures trading. In other words, there is little evidence to suggest that the establishment of futures trading destabilize the pan European securitized real estate market. The finding offers further evidence to support our baseline findings.

Comparable volatility pattern is also evident in the FTSE EPRA/NAREIT Eurozone index. The inception of the FTSE EPRA/NAREIT Eurozone index futures on $1^{\text {st }}$ October 2007 fell into the high-volatility period. However, a gradual transition toward the low-volatility phase occurred in March 2008. In August 2008, a jump in the volatility state was evident. In contrast, it did not last permanently in which the market switched back to the low-volatility phase in April 2009 and only showed one temporary phase of high volatility in April 2010. As a result, there is no evidence to support the assertion of the onset of futures trading destabilized the volatility of the securitized real estate markets in the Eurozone.

To sum up, little evidence is available to demonstrate a clear sustained increase in spot volatility after the introduction of futures trading. This reflects that the establishment of futures trading did not destabilize the underlying real estate market. Indeed, the temporary 
phases of high volatility offer further support to our discussion earlier in which higher volatility in the post-futures period at least some of the increase to the events surrounding the financial crisis can be attributed to other market-phenomenon rather than futures trading.

\section{4: Hedging Effectiveness}

Whilst the preceding sections have considered the impact of futures on the underlying spot market, our attention now turns to the ability of the contracts to act as effective hedges, with is one of the key characteristics of stock index futures generally (Darrat \& Rahman, 1995). Specifically, there is the question of whether such contracts can act as effective risk management tools. This is a key issue for investors and one that will enable more informed investment decision making. The initial results from this analysis are reported in Table 7 and the findings for the entire sample period, as shown in Panel A, demonstrate that the panEurope contracts are effective hedging instruments, with a level of risk reduction of $65 \%$. This equates to a reduction in the daily standard deviation from $2 \%$ to $0.7 \%$, indicating that the contracts are effective hedging instruments. Another important observation is that both hedging strategies (naïve and OLS) offer very comparable hedging results, signifying that the hedging efficiency of the contracts is robust to different hedging strategies. Similar results are were reported by Lee \& Lee (2012) with respect to the REIT markets in Australia and Japan. The strong hedging results indicate that the introduction of futures contracts specifically written on real estate security indices can add substantially to investors' opportunity sets through the enhancement of performance. In addition, the findings also support the arguments of Liang et al. (1998) and Lee \& Lee (2012) with respect to the importance of establishing dedicated real estate security futures contracts. 
The results with respect to the Eurozone specific index and contract are broadly similar. Both hedging strategies produce results that imply a level of risk reduction of $60 \%$ over the period July 2008-September 2010. However, the Eurozone contracts did provide somewhat weaker results compared to the overall European case. One possible explanation relates to the differences in the volatility of the underlying market. As noted by Lee \& Lee (2012), a volatile spot market can lead to enhanced hedging results. Earlier in the paper the differences in composition between the two indices was noted with respect to trading. This is also a factor in their volatility. Over the sample period the standard deviation of the FTSE EPRA/NAREIT Europe index $(2.02 \%)$ was slightly higher than that of the FTSE EPRA/NAREIT Eurozone index (1.98\%). This possible explanation is further confirmed by considering the hedging effectiveness across two sub-periods, the results for displayed in Panels B and C of Table 7.

\section{$\{$ Insert Table 7\}}

It is noticeable that the hedging effectiveness of the FTSE EPRA/NAREIT Europe futures contract increased markedly during the financial crisis, in that the reduction in risk, $74 \%$, was of a larger magnitude than observed over the entire sample. In the second sub-period the level of risk reduction fell to $47 \%$. This can in part be explained by the less volatile market conditions in this second period. Similar results are also found with respect to the Eurozone index and contracts with an initial risk reduction figure of $70 \%$ declining to $41 \%$. This would again imply that the contracts achieved better hedging results in the more volatile period. The results are also consistent with Newell (2010) who found that A-REIT futures were widely used by institutional investors during the financial crisis. Importantly, the finding also 
indicates that European investors should more seriously consider the use of futures contracts during periods of high uncertainty and volatility. This provides additional evidence with respect to the economic usefulness of the contracts. In addition, the strong hedging results also provide some indirect support to the notion of a stabilizing effect brought about by the introduction of a futures market on listed real estate. As highlighted by McKenzie et al. (2001), a futures market can facilitate investors' hedging strategy in that it offers opportunities for investors, reducing therefore their reliance on spot hedging strategies. ${ }^{9}$

The final issue to be considered in the current paper concerns the pan European nature of the indices used. Unlike the majority of stock index futures, and specifically the REIT contracts available in the U.S., Australia and Japan, the European market is not centred on domestic indices. Given the U.K. real estate equity market was ranked as the $2^{\text {nd }}$ largest market in Europe (EPRA, 2011), it is reasonable to expect the U.K. investors would have a greater demand to hedge the risk of their portfolios. In addition, its size would mean that any pan European investor would be unlikely to hold negligible holdings in the U.K. sector. These elements may help to explain the difference in trading volumes in the two contracts (the Europe and Eurozone), with substantially higher trading seen in the wider Europe contract. However, there are further implications. The Eurozone Index is largely centred on a small number of large markets, the biggest being France. In contrast, the Europe Index was large weightings in both these markets and the U.K. This naturally raises the possibility that U.K. investors have a disincentive in using the contracts to hedge their portfolios, particularly if those portfolios are predominantly U.K. in focus. In order to consider this we assess the effectiveness of using the Europe contracts in hedging the U.K. market, as proxied by the equivalent British FTSE EPRA/NAREIT index. The results are reported in Table 8. 


\section{\{Insert Table 8\}}

The results reveal that hedging U.K. exposure through the use of the pan-European contract does result in substantial benefits in terms of risk reduction. Risk reduction figures to the order of $36 \%$ to $56 \%$, reflecting that U.K. investors can obtain benefits from their use. The fact that hedging benefits do occur would support the explanation is to why trading volumes are substantially larger with the Europe contracts in comparison to those concentrating solely on the Eurozone. However, the results also reveal that the hedging effectiveness is noticeably weaker compared to the preceding results reported in Table 7 . This suggests that a dedicated U.K. investor would achieve lower hedging benefits by using the FTSE ERPA/NAREIT Europe index futures compared with pan-European investors. It does need to be made clear that this is probably true in the case of every single individual country and domestic investors within them. The situation is however extenuated in a U.K. case due to the relative size of its listed market. The largest European market, in terms of market capitalization if not trading volume, is France. However, domestic French investors would possibly see less of an impact due to the high weighting placed upon the French market in the Eurozone index. Furthermore, it should also be noted that we ignore the foreign exchange risk present in when considering a U.K. investors, and therefore assumedly Sterling denominated. This finding does raise questions over the choice of launching contracts on an international basis and the possibility of latent demand for a U.K. specific contract.

\section{5: Concluding Comments}

Since the launch of real estate security futures contracts in Europe in 2007 there has been increasing interest on the part of investors. However, there have been no academic pieces of 
work dedicated to the impact of their introduction on the listed real estate sector in Europe. The current study provides a number of important insights. Firstly, an investigation of the returns in the FTSE ERPA/NAREIT Europe and Eurozone indices find little evidence to support the view that the introduction of index futures contracts had a destabilizing impact on the underlying market. In particular, no evidence is found that would imply that the introduction of futures contracts have led to an increase in underlying volatility. Rather, the empirical results imply that futures trading has led to an improvement in the information flow in the European listed real estate sector. It also appears that the volatility of real estate equities is negatively associated with the expected futures trading volume and open interest, confirming the stabilizing role of futures trading. These findings support the view that futures markets can improve liquidity provision and depth in an underlying spot market. Secondly, the hedging effectiveness analysis further illustrates the economic significance of European listed real estate futures. The results confirm that both contracts can be used as effective hedging instruments. In addition, the sub-period analysis shows that enhanced hedging results are documented during more volatile periods. The one caveat that does however need to be noted with respect to the contracts use in a hedging context relates to the cross-border nature of the indices used. This does lead, as the evidence with respect to the U.K. illustrates, to a reduction in hedging effectiveness in the case of a purely domestic investor.

\section{References}

Aggarwal, R. (1988) Stock Index Futures and Cash Market Volatility. Review of Futures Markets, 7, 290-299.

Andani, A., Lafuente, J. A. \& Novales, A. (2009) Liquidity and Hedging Effectiveness Under Futures Mispricing: International Evidence. Journal of Futures Markets, 29(11), 1050-1066.

Antoniou, A. \& Holmes, P. (1995) Futures Trading, Information and Spot Price Volatility: Evidence for the FTSE-100 Stock Index Futures Contract using GARCH. Journal of Banking and Finance, 19(1), 117-129. 
Antoniou, A., Holmes, P. \& Priestley, R. (1998), The Effects of Stock Index Futures Trading on Stock Index Volatility: An Analysis Volatility: An Analysis of the Asymmetric Response of Volatility to News. Journal of Futures Markets, 18(2), 1195-1228.

Bae, S. C., Kwon, T. H. \& Park, J. W. (2004) Futures Trading, Spot Market Volatility, And Market Efficiency: The Case of the Korean Index Futures Markets. Journal of Futures Markets, 24(12), 11951228.

Bessembinder, H. \& Seguin, P. J. (1992) Futures-trading Activity and Stock Price Volatility. Journal of Finance, 47(5), 2015-2034.

Bessembinder, H. \& Seguin, P. J. (1993) Price Volatility, Trading Volume and Market Depth: Evidence from Futures Markets. Journal of Financial and Quantitative Analysis, 28(1), 21-39.

Bohl, M. T., Salm, C. A. \& Wilfling, B. (2011) Do Individual Index Futures Investors Destrablize the Underlying Spot Market? Journal of Futures Markets, 31(1), 81-101.

Brounen, D. \& Ben-Hamo, Y. (2009) Calender Anomalies: The Case of International Property Shares. Journal of Real Estate Finance and Economics, 38(2), 115-136.

Chang, E. C., Cheng, J. W. \& Pinegard, J. M. (1999) Does Futures Trading Increase Stock Market Volatility? The case of the Nikkei Stock Index Futures Markets. Journal of Banking and Finance, 23(5), 727-753

Chaudhry, M., Christie-David, R. \& Webb, J. R. (2010) REITs: Hedging and Diversification Possibilities. Journal of Real Estate Portfolio Management, 16(3), 217-226.

Clayton, J. (2007) Commercial Real Estate Derivatives: The Developing U.S. Market. Real Estate Issues, Fall, 33-40.

Cotter, J. \& Stevenson, S. (2006) Multivariate Modeling of Daily REIT Volatility. Journal of Real Estate Finance and Economics, 32(3), 305-325.

Cotter, J. \& Stevenson, S. (2008) Modeling Long Memory in REITs. Real Estate Economics, 36(3), 533-554.

Cox, C. C. (1976) Futures Trading and Market Information. Journal of Political Economy, 84(6), 129137.

Daigler, R. T. \& Wiley, M. K. (1999) The Impact of Trader Type on the Futures Volatility-Volume Relation. Journal of Finance, 54(6), 2297-2316.

Darrat, A. F. \& Rahman, S. (1995) Has Futures Trading Activity caused Stock Price Volatility? Journal of Futures Markets, 15(5), 537-557.

Edwards, F. R. (1988a) Futures Trading and Cash Market Volatility: Stock Index and Interest Rates Futures. Journal of Futures Markets, 8(4), 421-439.

Edwards, F. R. (1988b) Does Futures Trading Increase Stock Market Volatility? Financial Analysts Journal, 44(1), 63-69.

EPRA (2011) EPRA Research: Monthly Statistical Bulletin June 2011, Brussels, Belgium, European Public Real Estate Association, 1-220

Figlewski, S. (1981) Futures Trading and Volatility in the GNMA Market. Journal of Finance, 36(2), 445-456.

Figlewski, S. (1984) Hedging Performance and Basis Risk in Stock Index Futures. Journal of Finance, 39(3), 657-669. 
Giliberto, M. (1993) Measuring Real Estate Returns: The Hedged REIT Index. Journal of Portfolio Management, 19(3), 94-99.

Gray, S.F. (1996) Modeling the Conditional Distribution of Interest Rates as a Regime-switching Process. Journal of Financial Economics, 42, 27-62.

Gulen, H. \& Mayhew, S. (2000) Stock Index Futures Trading and Volatility in International Equity Markets. Journal of Futures Markets, 20(7), 661-685.

Harris, L. (1989) The October 1987 S\&P 500 Stock-futures Basis. Journal of Finance, 44(1), 77-99.

Holmes, P. (1996) Stock-index Futures Hedging, Duration Effects, Expiration Effects and Hedge Ratio Stability. Journal of Business Finance and Accounting, 23(1), 63-77.

Hoesli, M. \& Lekander, J. (2008) Real Estate Portfolio Strategy and Product Innovation in Europe. Journal of Property Investment and Finance, 26(2), 162-176.

Jirasakuldech, B., Campbell, R.D. \& Emekter, R. (2009). Conditional Volatility of Equity Real Estate Investment Trust Returns: A Pre and Post-1993 Comparison, Journal of Real Estate Finance and Economics, 38(2), 137-154.

Kaldor, N. (1939) Speculation and Economic Stability. Review of Economic Studies, 7(1), 1-27.

Knight Frank (2010) 2010 Global Real Estate Market: Annual Review and Outlook. Knight Frank, London, 1-26.

Lecomte, P. \& McIntosh, W. (2006) Designing Property Futures Contracts and Options based on NCREIF Property Indices. Journal of Real Estate Portfolio Management, 12(2), 119-153.

Lee, C. L. (2009) Volatility Transmission in Australian REIT Futures. Journal of Real Estate Portfolio Management, 15(3), 221-238.

Lee, C. L. \& Lee, M.-L. (2012) Hedging Effectiveness of REIT Futures. Journal of Property Investment and Finance, 30(3), 257-281.

Lee, S. B. \& Ohk, K. Y. (1992) Stock Index Futures Listing and Structural Change in Time-Varying Volatility. Journal of Futures Markets, 12(5), 493-509.

Lenkkeri, V., Marquering, W. \& Strunkmann-Meister, B. (2006) The Friday Effect in European Securitized Real Estate Index Returns. Journal of Real Estate Finance and Economics, 33(1), 31-50.

Liang, Y., Seiler, M. J. \& Chatrath, A. (1998) Are REIT Returns Hedgable? Journal of Real Estate Research, 16(1), 87-97.

Liow, K.H. (2009) Long-Term Memory in Volatility: Some Evidence from International Securitized Real Estate Markets, Journal of Real Estate Finance and Economics, 39(4), 415-438.

Liow, K.H. \& Ibrahim, M.F. (2010) Volatility Decomposition and Correlation in International Securitized Real Estate Markets. Journal of Real Estate Finance and Economics, 40, 415-438

Lizieri C., Marcato G., Ogden P. \& Baum, A. (2011). Pricing Inefficiencies in Private Real Estate Markets Using Total Return Swaps, Journal of Real Estate Finance and Economics, forthcoming.

McKenzie, M. D., Brailsford, T. J. \& Faff, R. W. (2001) New Insights into The Impact of the Introduction of Futures Trading on Stock Price Volatility. Journal of Futures Markets, 21(3), 237255 .

Newell, G. (2010) The Effectiveness of A-REIT Futures as a Risk Management Strategy in the Global Financial Crisis. Pacific Rim Property Research Journal, 16(3), 339-357. 
Newell, G. \& Tan, Y. K. (2004) The Development and Performance of Listed Property Trust Futures. Pacific Rim Property Research Journal, 10(2), 132-145.

Nomikos, N.K. \& Pouliasis, P.K. (2011) Forecasting Petroleum Futures Markets Volatility: The Role of Regimes and Market Conditions. Energy Economics, 33, 312-337.

NYSE (2011) NYSE LIFFE European Derivatives Market: NYSE LIFFE Annual \& Monthly Statistics, Amsterdam, NYSE LIFFE,

Ong, S. E. \& Ng, K. H. (2009) Developing the Real Estate Derivative Market for Singapore: Issues and Challenges. Journal of Property Investment and Finance, 27(4), 425-432.

Oppenheimer, P. H. (1996) Hedging REIT Returns Using the Futures Markets. Journal of Real Estate Portfolio Management, 2(1), 41-53.

Pericli, A. \& Koutmos, G. (1997) Index Futures and Options and Stock Market Volatility. Journal of Futures Markets, 17(8), 957-974.

Santoni, G. J. (1987) Has Programmed Trading made Stock Prices more Volatile? Review-Federal Reserve Bank of St. Loius, 69(5), 18-29.

Stein, J. C. (1987) Informational Externalities and Welfare-reducing Speculation. Journal of Political Economy, 95(6), 1123-1145.

Stevenson, S. (2000) International Real Estate Diversification: Empirical Tests Using Hedged Indices. Journal of Real Estate Research, 19(1/2), 105-131.

Stevenson, S. (2002) An Examination of Volatility Spillovers in REIT Returns. Journal of Real Estate Portfolio Management, 8(3), 229-238.

Stoll, H. R. \& Whaley, R. E. (1988) Volatility and Futures: Message versus Messenger. Journal of Portfolio Management, 14(2), 20-22.

Watanabe, T. (2001) Price Volatility, Trading Volume and Market Depth: Evidence from the Japanese Stock Index Futures Market. Applied Financial Economics, 11(6), 651-658.

Wong, S. K., Yiu, C. Y., Tse, M. K. S. \& Chau, K. W. (2006) Do the Forward Sales of Real Estate Stabilize Spot Prices? . Journal of Real Estate Finance and Economics, 32(3), 281-293.

Working, H. (1953) Futures Trading and Hedging. American Economic Review, 43(3), 314-343. 
Table 1: FTSE ERPA/NAREIT Europe and Eurozone Index Futures Contracts

\begin{tabular}{lll}
\hline Contract & $\begin{array}{l}\text { FTSE ERPA/NAREIT Europe } \\
\text { Index Futures }\end{array}$ & $\begin{array}{l}\text { FTSE ERPA/NAREIT } \\
\text { Eurozone Index Futures }\end{array}$ \\
\hline Exchange & NYSE Liffe Euronext Paris & NYSE Liffe Euronext Paris \\
Currency & Euro $(€)$ & Euro $(€)$ \\
Introduced Year & 2007 & 2007 \\
Underlying Index & FTSE ERPA/NAREIT Europe & FTSE ERPA/NAREIT Euro \\
& Index & Zone Index \\
Contract Size & $€ 10$ per index point & $€ 10$ per index point \\
Trading Months & Nearest three quarterly & Nearest three quarterly \\
& maturities (March, June, & maturities (March, June, \\
& September and December) & September and December) \\
Last Trading Day & The third Friday of the & The third Friday of the \\
& expiration month at 5.45pm CET & expiration month at 5.45pm CET \\
\hline
\end{tabular}

Source: NYSE Liffe Euronext (2011) 
Table 2: Effect of Futures on Real Estate Security Market Volatility

\begin{tabular}{lcc}
\hline Market & Europe & Eurozone \\
\hline Panel A: Mean Equation & & \\
\hline Constant $\left(\mathrm{a}_{0}\right)$ & 0.001 & 0.001 \\
& $(5.450)^{* * *}$ & $(5.976)^{* * *}$ \\
Lag Return $\left(\mathrm{a}_{1}\right)$ & 0.052 & 0.061 \\
& $(1.818)^{* * *}$ & $(2.062)^{* *}$ \\
GFC $\left(\mathrm{a}_{2}\right)$ & -0.003 & -0.002 \\
& $(-3.014)^{* * *}$ & $(-2.560)^{* *}$ \\
\hline Panel B: Variance Equation & & $1.94 \times 10^{-6}$ \\
\hline Constant $\left(\alpha_{0}\right)$ & $1.17 \times 10^{-6}$ & $(2.812)^{* * *}$ \\
& $(2.470)^{* * *}$ & 0.153 \\
ARCH $\left(\alpha_{1}\right)$ & 0.052 & $(5.945)^{* * *}$ \\
& $(5.748)^{* * *}$ & 0.837 \\
GARCH$\left(\alpha_{2}\right)$ & 0.891 & $(35.277)^{* * *}$ \\
& $(49.377)^{* * *}$ & $4.35 \times 10^{-6}$ \\
$\mathrm{D}_{\mathrm{F}}\left(\alpha_{3}\right)$ & $1.23 \times 10^{-6}$ & $(1.976)^{* *}$ \\
\hline Panel C: Diagnosis Statistics & $(0.901)$ & \\
\hline $\mathrm{Q}(6)$ & & 5.437 \\
& 6.315 & $(0.489)$ \\
& $(0.389)$ & 13.618 \\
& 9.493 & $(0.326)$ \\
\hline
\end{tabular}

Notes: This table reports estimated coefficients from a $\operatorname{GARCH}(1,1)$ model with dummy variable for futures trading. Figures in parentheses in Panels A and B are the Bollerslev-Wooldridge robust standard errors. *,**,*** denotes significance at the $10 \%, 5 \%$ and $1 \%$ level respectively. 
Table 3: FTSE EPRA/NAREIT Europe Index: Pre- and Post-Futures

\begin{tabular}{lcc}
\hline Period & Pre-Futures & Post-Futures \\
\hline Panel A: Mean Equation & & 0.001 \\
\hline Constant $\left(\mathrm{a}_{0}\right)$ & 0.001 & $(2.357)^{* * *}$ \\
& $(4.786)^{* * *}$ & 0.054 \\
Lag Return $\left(\mathrm{a}_{1}\right)$ & 0.051 & $(1.412)$ \\
& $(1.209)$ & -0.003 \\
GFC $\left(\mathrm{a}_{2}\right)$ & -0.004 & $(-2.616)^{* * *}$ \\
\hline Panel B: Variance Equation & $(-0.794)$ & $3.35 \times 10^{-6}$ \\
\hline Constant $\left(\alpha_{0}\right)$ & & $(1.776)^{*}$ \\
& $7.47 \times 10^{-7}$ & 0.132 \\
ARCH $\left(\alpha_{1}\right)$ & $(2.092)^{* *}$ & $(4.806)^{* * *}$ \\
& 0.083 & 0.868 \\
GARCH$\left(\alpha_{2}\right)$ & $(4.230)^{* * *}$ & $(34.214)^{* * *}$ \\
& 0.917 & \\
\hline Panel C: Diagnosis Statistics & $(53.504)^{* * *}$ & $(0.245$ \\
Q(6) & & 9.271 \\
Q(12) & 3.654 & $(0.680)$ \\
\hline
\end{tabular}

Notes: This table reports estimated coefficients for mean and variance equations of $\operatorname{GARCH}(1,1)$. Figures in parentheses in Panels A and B are the Bollerslev-Wooldridge robust standard errors. *, **, *** denotes significance at the $10 \%, 5 \%$ and $1 \%$ level respectively. 
Table 4: FTSE EPRA/NAREIT Eurozone Index: Pre- and Post-Futures

\begin{tabular}{lcc}
\hline Period & Pre-Futures & Post-Futures \\
\hline Panel A: Mean Equation & & 0.002 \\
\hline Constant $\left(\mathrm{a}_{0}\right)$ & 0.001 & $(2.670)^{* * *}$ \\
& $(5.150)^{* * *}$ & 0.054 \\
Lag Return $\left(\mathrm{a}_{1}\right)$ & 0.073 & $(1.322)$ \\
& $(1.704)^{*}$ & -0.002 \\
GFC $\left(\mathrm{a}_{2}\right)$ & -0.003 & $(-2.306)^{* * *}$ \\
\hline Panel B: Variance Equation & $(-0.444)$ & $6.28 \times 10^{-6}$ \\
\hline Constant $\left(\alpha_{0}\right)$ & & $(2.476)^{* *}$ \\
& $1.30 \times 10^{-6}$ & 0.153 \\
ARCH $\left(\alpha_{1}\right)$ & $(1.992)^{* *}$ & $(4.757)^{* * *}$ \\
& 0.122 & 0.837 \\
GARCH $\left(\alpha_{2}\right)$ & $(3.577)^{* * *}$ & $(27.740)^{* * *}$ \\
\hline Panel C: Diagnosis Statistics & 0.874 & \\
\hline $\mathrm{Q}(6)$ & $(29.211)^{* * *}$ & 8.519 \\
& & $(0.202)$ \\
Q(12) & 3.906 & 11.371 \\
& $(0.689)$ & $(0.497)$ \\
\hline
\end{tabular}

Notes: This table reports estimated coefficients for mean and variance equations of $\operatorname{GARCH}(1,1)$. Figures in parentheses in Panels A and B are the Bollerslev-Wooldridge robust standard errors. *,**, *** denotes significance at the $10 \%, 5 \%$ and $1 \%$ level respectively. 
Table 5: Volatility and Expected \& Unexpected Futures Trading Activity

\begin{tabular}{lcc}
\hline Market & Europe & Euro Zone \\
\hline Panel A: Mean Equation & & \\
\hline Constant $\left(\mathrm{a}_{0}\right)$ & -0.001 & $-2.94 \times 10^{-5}$ \\
& $(-0.658)$ & $(-0.010)$ \\
Lag Return $\left(\mathrm{a}_{1}\right)$ & 0.053 & 0.040 \\
& $(0.883)$ & $(1.031)$
\end{tabular}

\begin{tabular}{lcc}
\hline Panel B: Variance Equation & & \\
\hline Constant $\left(\alpha_{0}\right)$ & $2.81 \times 10^{-4}$ & $9.40 \times 10^{-5}$ \\
ARCH $\left(\alpha_{1}\right)$ & $(2.082)^{* *}$ & $(3.006)^{* * *}$ \\
& 0.150 & 0.097 \\
GARCH $\left(\alpha_{2}\right)$ & $(2.038)^{* *}$ & $(4.334)^{* * *}$ \\
Expected Volume & 0.600 & 0.873 \\
& $(3.660)^{* * *}$ & $(31.390)^{* * *}$ \\
Unexpected Volume & $-7.90 \times 10^{-8}$ & $-2.70 \times 10^{-7}$ \\
& $(-2.135)^{* *}$ & $(-1.878)^{*}$ \\
Expected Open Interest & $4.00 \times 10^{-8}$ & $2.02 \times 10^{-7}$ \\
& $(0.720)$ & $(2.375)$ \\
Unexpected Open Interest & $-1.08 \times 10^{-8}$ & $-4.10 \times 10^{-9}$ \\
& $(-2.075)^{* *}$ & $(-1.138)$ \\
Monday & $4.32 \times 10^{-9}$ & $-4.76 \times 10^{-8}$ \\
& $(0.128)$ & $(-1.369)$ \\
Tuesday & $-6.61 \times 10^{-5}$ & $-8.86 \times 10^{-5}$ \\
& $(-0.480)$ & $(-1.741)^{*}$ \\
Wednesday & $-5.11 \times 10^{-5}$ & $-6.24 \times 10^{-5}$ \\
& $(-0.454)$ & $(-1.582)$ \\
Thursday & $-4.00 \times 10^{-5}$ & $-7.27 \times 10^{-5}$ \\
& $(-0.342)$ & $(-1.689)^{*}$ \\
\hline Panel C: Diagnosis Statistics & $-2.07 \times 10^{-5}$ & $-6.48 \times 10^{-5}$ \\
\hline Q(6) & $(-0.143)$ & $(-1.328)$ \\
Q(12) & 6.069 & 2.494 \\
& $(0.416)$ & $(0.869)$ \\
\hline
\end{tabular}

Notes: This table reports estimated coefficients from a GARCH(1,1) model with expected and unexpected futures-trading activity. Figures in parentheses in Panels A and B are the BollerslevWooldridge robust standard errors. *, **, *** denotes significance at the $10 \%, 5 \%$ and $1 \%$ level respectively. 
Table 6: Markov-Switching-GARCH Model of Real Estate Security Market Volatility

\begin{tabular}{|c|c|c|}
\hline Market & Europe & Eurozone \\
\hline \multicolumn{3}{|c|}{ Panel A: Mean Equation } \\
\hline \multirow[t]{2}{*}{ Constant $\left(a_{02}\right)$} & 0.001 & 0.001 \\
\hline & $(5.416)^{* * *}$ & $(6.263)^{* * *}$ \\
\hline \multirow[t]{2}{*}{ Lag Return $\left(a_{11}\right)$} & 0.069 & 0.072 \\
\hline & $(2.038) * *$ & $(2.081)^{* *}$ \\
\hline \multirow[t]{2}{*}{ Lag Return $\left(a_{12}\right)$} & 0.068 & 0.086 \\
\hline & $(1.855)^{*}$ & $(1.888)^{*}$ \\
\hline \multicolumn{3}{|c|}{ Panel B: Variance Equation } \\
\hline \multirow[t]{2}{*}{ Constant $\left(\alpha_{01}\right)$} & $6.081 \times 10-5$ & $2.451 \times 10-5$ \\
\hline & $(3.453)^{* * *}$ & $(3.645)^{* * *}$ \\
\hline \multirow[t]{2}{*}{ Constant $\left(\alpha_{02}\right)$} & $1.834 \times 10-5$ & $2.267 \times 10-5$ \\
\hline & $(4.348)^{* * *}$ & $(6.389)^{* * *}$ \\
\hline \multirow[t]{2}{*}{$\operatorname{ARCH}\left(\alpha_{11}\right)$} & 0.095 & 0.135 \\
\hline & $(3.307)^{* * *}$ & $(4.492)^{* * *}$ \\
\hline \multirow[t]{2}{*}{$\mathrm{ARCH}\left(\alpha_{12}\right)$} & 0.058 & 0.181 \\
\hline & $(1.297)$ & $(2.616)^{* * *}$ \\
\hline \multirow[t]{2}{*}{$\operatorname{GARCH}\left(\alpha_{21}\right)$} & 0.804 & 0.816 \\
\hline & $(17.751)^{* * *}$ & $(21.923) * * *$ \\
\hline \multirow[t]{2}{*}{$\operatorname{GARCH}\left(\alpha_{22}\right)$} & 0.415 & 0.022 \\
\hline & $(4.724)^{* * *}$ & $(0.847)$ \\
\hline
\end{tabular}




\section{Panel C: Transition Probabilities}

\begin{tabular}{lcc}
\hline $\mathrm{P}(1,1)$ & 0.992 & 0.994 \\
& $(287.156)^{* * * *}$ & $(268.347)^{* * *}$ \\
$\mathrm{P}(1,2)$ & 0.006 & 0.012 \\
& $(1.579)$ & $(1.365)$ \\
\hline
\end{tabular}

Panel D: Diagnosis Statistics

\begin{tabular}{lll}
\hline $\mathrm{Q}(6)$ & 2.948 & 1.271
\end{tabular}

$(0.815)$

$(0.973)$

$\mathrm{Q}(12)$

9.544

7.341

(0.656)

$(0.834)$

Notes: This table reports estimated coefficients for mean and variance equations of Markovswitching-GARCH(1,1). Figures in parentheses are $\mathbf{t}$ values. $* * *, * * *$ denotes significance at the $10 \%, 5 \%$ and $1 \%$ level respectively. 
Figure 1: Conditional Variance of the FTSE EPRA/NAREIT Europe Index

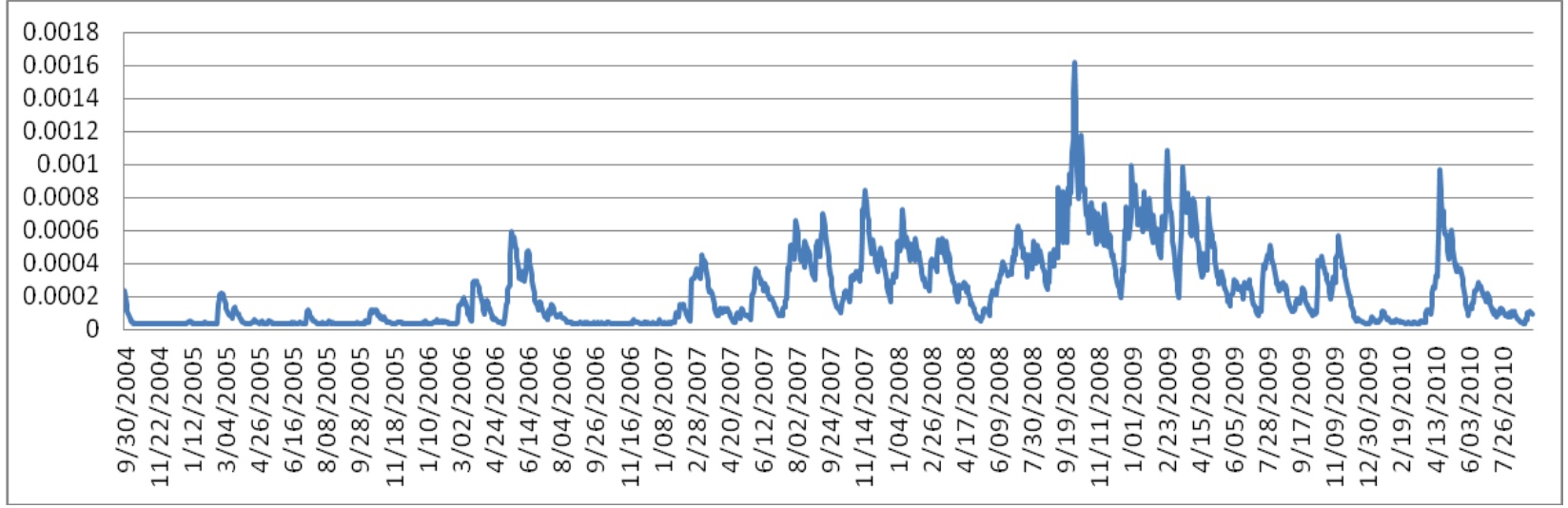

Figure 2: Conditional Variance of the FTSE EPRA/NAREIT Eurozone Index

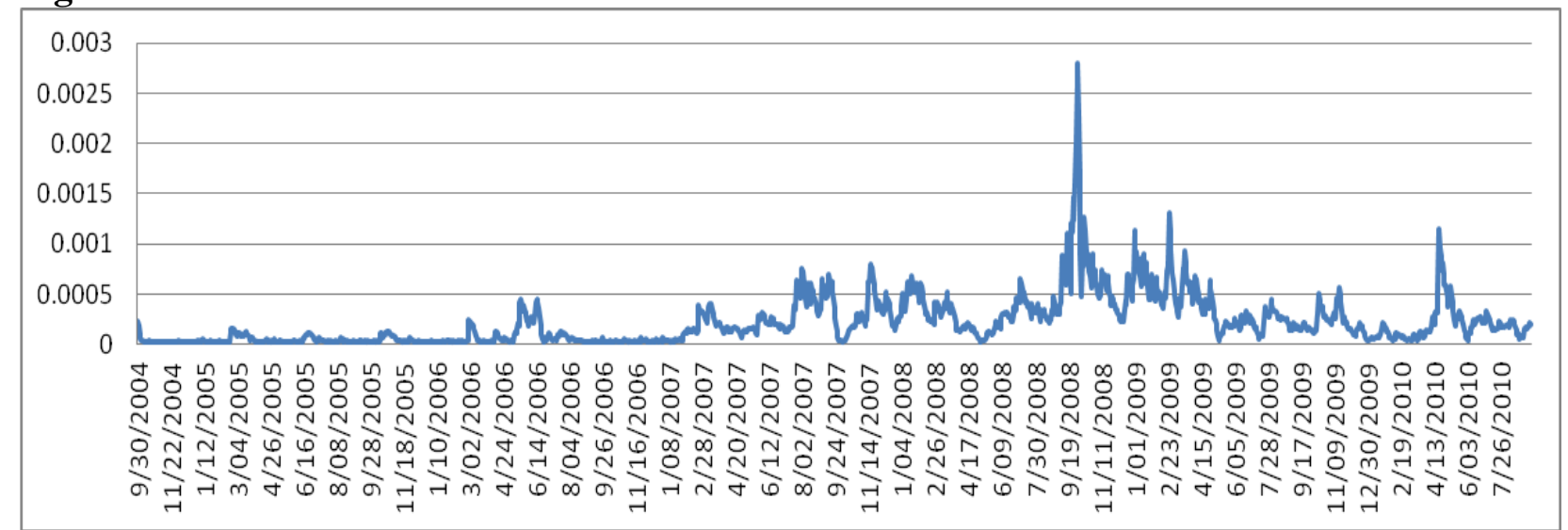


Table 7: Hedging Effectiveness of Europe Real Estate Securities Futures: Sub-Period Analysis

\begin{tabular}{|c|c|c|c|c|}
\hline & \multicolumn{2}{|c|}{ Europe Index } & \multicolumn{2}{|c|}{ Eurozone Index } \\
\hline & Risk (\%) & $\begin{array}{c}\text { Hedging } \\
\text { Effectiveness (\%) }\end{array}$ & Risk (\%) & $\begin{array}{c}\text { Hedging } \\
\text { Effectiveness } \\
(\%)\end{array}$ \\
\hline \multicolumn{5}{|c|}{ Panel A: July 2008-September 2010} \\
\hline Unhedged portfolio & 2.021 & & 1.979 & \\
\hline \multicolumn{5}{|l|}{ Hedged portfolio } \\
\hline Naive hedge & 0.714 & 64.685 & 0.788 & 60.199 \\
\hline OLS & 0.705 & 65.116 & 0.788 & 60.179 \\
\hline \multicolumn{5}{|c|}{ Panel B: July 2008-May 2009} \\
\hline Unhedged portfolio & 2.720 & & 2.642 & \\
\hline \multicolumn{5}{|l|}{ Hedged portfolio } \\
\hline Naive hedge & 0.706 & 74.041 & 0.767 & 70.985 \\
\hline OLS & 0.709 & 73.952 & 0.780 & 70.473 \\
\hline \multicolumn{5}{|c|}{ Panel C: June 2009-September 2010} \\
\hline Unhedged portfolio & 1.349 & & 1.353 & \\
\hline \multicolumn{5}{|l|}{ Hedged portfolio } \\
\hline Naive hedge & 0.720 & 46.651 & 0.803 & 40.675 \\
\hline OLS & 0.703 & 47.852 & 0.795 & 41.278 \\
\hline
\end{tabular}

Notes: Hedging effectiveness is measured as: $\frac{\sigma_{\mathrm{u}}-\sigma_{\mathrm{h}}}{\sigma_{\mathrm{u}}} \times 100$ 
Table 8: Hedging Effectiveness of the FTSE EPRA/NAREIT Europe Index Futures for UK Investors

Risk (\%) Hedging Effectiveness

$(\%)$

\begin{tabular}{lll}
\hline Panel A: July 2008 - September 2010 & & \\
\hline Unhedged portfolio & 2.686 & \\
Hedged portfolio & & \\
$\quad$ Naive hedge & 1.353 & 59.644 \\
$\quad$ OLS & 1.326 & \\
\hline Panel B: July 2008 - May 2009 & 3.672 & \\
\hline Unhedged portfolio & & 53.905 \\
Hedged portfolio & 1.692 & 56.423 \\
$\quad$ Naive hedge & 1.600 & \\
$\quad$ OLS & 1.720 & \\
\hline Panel B: June 2009 - September 2010 & & 38.018 \\
\hline Unhedged portfolio & 1.066 & 35.748 \\
Hedged portfolio & 1.105 & \\
$\quad$ Naive hedge & & \\
$\quad$ OLS
\end{tabular}

Notes: The risk of the unhedged portfolio for UK investors is measured by the FTSE ERPA/NAREIT UK Index in Euro's. 


\section{Endnotes:}

${ }^{1}$ To check the robustness of our baseline results, a robustness check was performed. Oct 2002 (5 years before the onset of futures trading) was selected. However, it did not change the conclusion of futures trading did not destabilise the underlying spot market.

${ }^{2}$ A robustness check of the sensitivity of our results to currency denomination was also performed in which our models were re-run with the dataset in US dollar. Little variation was observed. Specifically, the baseline findings are robust in which no significant increase in volatility that is attributed to the introduction of futures trading.

${ }^{3}$ Results from Augmented Dickey-Fuller and Phillips-Perron unit root tests show that all of the data is stationary. These results are available from the authors on request.

${ }^{4}$ The GFC period is from September 2007-June 2009. This is consistent with the studies such as Newell (2010) and KnightFrank (2010) in which a recovery sign was evident since Q2, 2009. Robustness checks were also performed. Different periods were selected (1) Oct 07-Dec 09, (2) Sept 07-March 09 and (3) Oct 07-May 09. The robustness checks show that the preceding results are robust.

${ }^{5} \mathrm{~A}$ unit root test was performed for these variables; the results show these variables are stationary.

${ }^{6}$ Naturally, a third time dummy representing the pre-crisis period cannot be introduced as it would lead to perfect multicollinearity. The full sets of results are available from the authors.

${ }^{7}$ Gulen \& Mayhen (2000) do highlight the importance of accounting for movements in the world index in the consideration of changes in underlying volatility. To further control for the effect of other determinants of volatility, the FTSE Eurofirst 300 index, the FTSE Eurofirst 300 Eurozone Index as well as the S\&P Global Property Index were introduced into our baseline models. Interestingly, the inclusions of these indices had little impact on our baseline results. The results also suggest that our results are robust to these alternative specifications. The full sets of results from these specifications are available from the authors on request.

${ }^{8}$ Interestingly, a negative relationship is observed between the forward and spot housing markets in Hong Kong by Wong et al. (2006), confirming that futures/forwards trading may enhance the information flows and reduce spot volatility.

${ }^{9}$ A robustness check with 10-day window was also performed, no significant difference is found. Thus, the baselines results are robust to the choice of estimation window. The full robustness results are available from the authors. 